\title{
Electrostatic Regulation of Blue Copper Sites
}

\author{
Daniel Bím, a Anastassia N. Alexandrova*a,b \\ aDepartment of Chemistry and Biochemistry, University of California, Los Angeles, 607 Charles E. Young Drive East, Los Angeles, CA 90095-1569, USA.

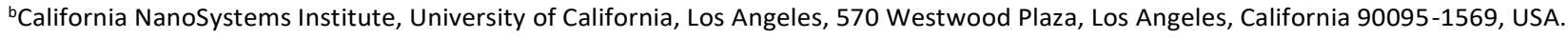 \\ *Corresponding author: ana@chem.ucla.edu
}

In the last 50 years, the blue copper proteins became central targets of investigation. Extensive experiments focused on the first- and secondcoordination spheres of $\mathrm{Cu}$ to probe the effect of local perturbations on its properties. We found that local electric fields, generated by charged residues evolutionarily placed throughout the protein edifice, constitute an additional significant factor regulating blue copper proteins. These fields are not random, but exhibit a highly specific directionality, negative with respect to $\overrightarrow{\mathrm{Cu}-\mathrm{Scys}_{\mathrm{s}}}$ and $\overrightarrow{\mathrm{Cu}}-\mathrm{S}_{\mathrm{Met}}$ in the $\mathrm{Cu}$ first shell. The field magnitude contributes to fine-tuning of the geometric and electronic properties of $\mathrm{Cu}$ sites in individual blue copper proteins. Specifically, the local electric fields evidently control the $\mathrm{Cu}-\mathrm{S}_{\mathrm{Met}}$ bond distance, $\mathrm{Cu}(\mathrm{II})-\mathrm{S}_{\mathrm{cys}}$ bond covalency, and the energies of the frontier molecular orbitals, which, in turn, govern the $\mathrm{Cu}(\mathrm{II} / \mathrm{I})$ reduction potential and the relative absorption intensities at $450 \mathrm{~nm}$ and $600 \mathrm{~nm}$.

\section{Introduction}

Blue copper proteins (BC; also type 1 or $\mathrm{T} 1$ proteins) are proteins that participate in the rapid long-range biological electron transfers. ${ }^{1-4}$ Their $\mathrm{Cu}$ (II) centers feature an intense $600-\mathrm{nm}$ band in the electronic absorption spectra, giving rise to their blue color and their name. A typical BC active site (e.g., in plastocyanin, azurin, rusticyanin, amicyanin) consists of the $\mathrm{Cu}$ (II) coordinated by $2 \mathrm{His}$, Cys, and Met ligands in the pseudotetrahedral geometry. ${ }^{5,6}$ Since the preferred coordination of $\mathrm{Cu}$ (II) complexes is square planar, ${ }^{4}$ it was initially thought that observed tetrahedral geometry is responsible for their distinct spectral features, including small EPR hyperfine splitting, and high $\mathrm{Cu}(\mathrm{II} / \mathrm{I})$ reduction potentials. ${ }^{7-15}$ Additionally, the unusual coordination, along with relatively small geometric changes between oxidized and reduced states (e.g., small angular distortion, small differences in $\mathrm{Cu}-\mathrm{L}$ bond lengths, and rigidity of proteins upon single-point mutations), ${ }^{16-22}$ laid the foundations of entatic ${ }^{23}$ and rack-induced ${ }^{24}$ concepts in bioinorganic chemistry. According to the entatic/rack hypothesis, the protein function (e.g., electron transfer) is empowered by keeping the active site in a distorted (compromised) structure between the two functional states; such as $\mathrm{Cu}(\mathrm{I})$ (tetrahedral) and $\mathrm{Cu}(\mathrm{II})$ (square planar) conformations in $\mathrm{BC}$ proteins. Hence, the reorganization energy of redox reaction is minimized, 4,25 and following the Marcus theory, ${ }^{26}$ the rate of electron transfer is enhanced. Note that electron-transfer proteins must operate near thermodynamic neutrality, making the argument of small reorganization energy critical for their proper biological function. ${ }^{4}$

However, the entatic/rack concepts were questioned both in computations and in spectroscopic studies. ${ }^{19,27}$ Solomon and co-workers demonstrated that tetrahedral structure is indeed preferred in Cu(II) BC proteins; however, not due to entatic/rack constraints of $\mathrm{Cu}$ (II) coordination geometry in a true sense but rather due to the $\mathrm{Cu}-\mathrm{S}_{\mathrm{Met}}$ bond elongation and $\mathrm{Cu}-\mathrm{S}_{\mathrm{Cys}}$ bond shortening in the $\mathrm{Cu}$ first ligand shell. ${ }^{19}$ Such distortions in $\mathrm{Cu}$ ligand field lowers the site's symmetry (i.e., orbital degeneracy) and eliminates the Jahn-Teller distorting forces otherwise present in tetrahedral $\mathrm{Cu}(\mathrm{II})$ complexes. ${ }^{28}$ The abnormally elongated axial $\mathrm{Cu}-\mathrm{S}_{\mathrm{Met}}$ and shortened equatorial $\mathrm{Cu}-\mathrm{S}_{\mathrm{Cys}}$ bonds are unique, and likely controlled by the constraints produced by the protein. ${ }^{29-31}$

It was recognized that $\mathrm{Cu}-\mathrm{S}_{\text {Met }}$ and $\mathrm{Cu}-\mathrm{S}_{\mathrm{Cys}}$ bonds are electronically and geometrically coupled, $2,12,19,32$ so that the weak $\mathrm{Cu}-\mathrm{S}_{\text {Met }}$ interaction is compensated by strengthening $\mathrm{Cu}$ $\mathrm{S}_{\mathrm{Cys}}$, together with increasing the $\mathrm{Cu}(\mathrm{II})-\mathrm{S}_{\mathrm{Cys}}$ bond covalency. 4,33 In turn, strong $\mathrm{Cu}-\mathrm{S}_{\mathrm{Cys}}$ is accountable for a strong electronic absorption at $600 \mathrm{~nm}$ due to $\mathrm{S}_{\mathrm{cys}} 3 \mathrm{p} \rightarrow \mathrm{Cu}$ (II) $3 \mathrm{~d}_{\mathrm{xz}-\mathrm{y} 2} \pi$ charge transfer. ${ }^{34-36}$ The high covalency of $\mathrm{Cu}(\mathrm{II}) 3 \mathrm{~d}_{\mathrm{x2}-\mathrm{y2}}$ HOMO also results in a small EPR hyperfine splitting. ${ }^{35}$ By regulating the strengths of the $\mathrm{Cu}-\mathrm{S}_{\mathrm{Met}}$ and $\mathrm{Cu}-\mathrm{S}_{\mathrm{Cys}}$ bonds, the $\mathrm{BC}$ proteins might thus tune their properties toward desired functionalities, including adjustment of $\mathrm{Cu}(\mathrm{II} / \mathrm{I})$ reduction potential or rate of electron transfer. ${ }^{31,35,37,38}$ However, the mechanism of such regulation remains debated.

Within the $\mathrm{Cu}(\mathrm{I})$ sites in the $\mathrm{BC}$ proteins, Solomon has argued that Met ligand is held in place by the protein environment i.e., in the entatic or rack-induced state. ${ }^{39}$ However, a discussion is complicated by the fact that there is not an unambiguous definition of what entasis is and/or how strain energy in the metal site should be quantified. ${ }^{27,40,41}$ As an example, Ryde et al. contrariwise proposed that BC proteins are not entatic. ${ }^{27}$ Instead, the Met residue was foreseen to be selected as a 'floppy' ligand with a flat potential energy surface to accommodate facile interchange between the two oxidation states and assist with rapid electron transfer. On the other hand, Hurd et al. ${ }^{42}$ computed much higher strain energies for plastocyanin when they included not only geometric constraints (i.e., covalent strain) but also protein electrostatics from $\mathrm{QM} / \mathrm{MM}$ calculations. The strain energies elevated by $\sim 10 \mathrm{kcal}$ $\mathrm{mol}^{-1}$. In plastocyanin, this suggests that protein electrostatics may play a significant role in $\mathrm{Cu}-\mathrm{S}_{\mathrm{Met}} / \mathrm{Cu}-\mathrm{S}_{\mathrm{Cys}}$ regulation and can contribute to plastocyanin function. Electrostatic interactions were also evidenced as predominant determinants of $\mathrm{Cu}(\mathrm{II} / \mathrm{I})$ 


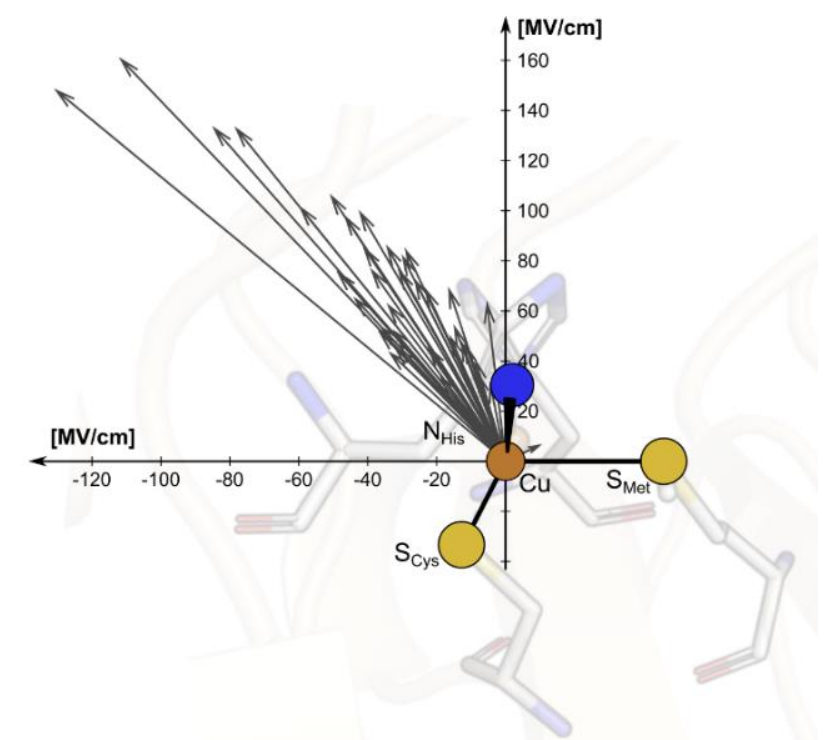

Figure 2. A graphical representation of the LEFs found in the series of $\mathrm{BC}$ proteins. The LEFs are plotted with gray arrows as vectors projected in the $\mathrm{Cu}-\mathrm{S}_{\mathrm{cys}} / \mathrm{Cu}_{\mathrm{S}} \mathrm{S}_{\mathrm{Met}}$ plane.

reduction potentials in the computational study of $B C$ azurin variants. ${ }^{43}$

Recently, we have demonstrated that heme-iron proteins exert highly specific intramolecular electric fields on their active sites and that there is a strong correlation between the direction and magnitude of this field and the protein function. ${ }^{44}$ Herein, we demonstrate that the local electric fields produced by the proteins of the $\mathrm{BC}$ family are likewise not randomly oriented and instead appear customized by the evolution to fine-tune the $B C$ centers' properties. This includes modifying the $B C$ site geometry, electronic structure, $\mathrm{BC}$ spectral features, and $\mathrm{Cu}(\mathrm{II} / \mathrm{I})$ reduction potentials.

\section{Results and Discussion}

The local electric fields in the active sites of blue copper proteins.

Employing the Erebus PDB protein substructure search server, ${ }^{45}$ we have identified 36 unique BC proteins with $2 \mathrm{His}$, Cys, Met coordination (see Computational Details section in the $\mathrm{SI}$ ). For this set of proteins, we analyzed the magnitudes of local electric fields (LEFs) in their active sites' $\mathrm{Cu}$, together with the geometrical features of the proteins' active sites from their crystal structures (Table S1). Note that the evaluated fields are induced by the entire protein outside of the $\mathrm{BC}$ active site, i.e., excluding the effects of coordinating residues and the $\mathrm{Cu}$ itself. The coordinating ligands thus do not contribute to the discussed LEFs, and the effect of LEFs is thereby additive to the effect of the first coordination sphere on the metal.

The overall LEF magnitudes range significantly in the protein series, from $14 \mathrm{MV} \mathrm{cm}^{-1}$ (1a3z; rusticyanin) to $165 \mathrm{MV} \mathrm{cm}^{-1}$ (1ezl;

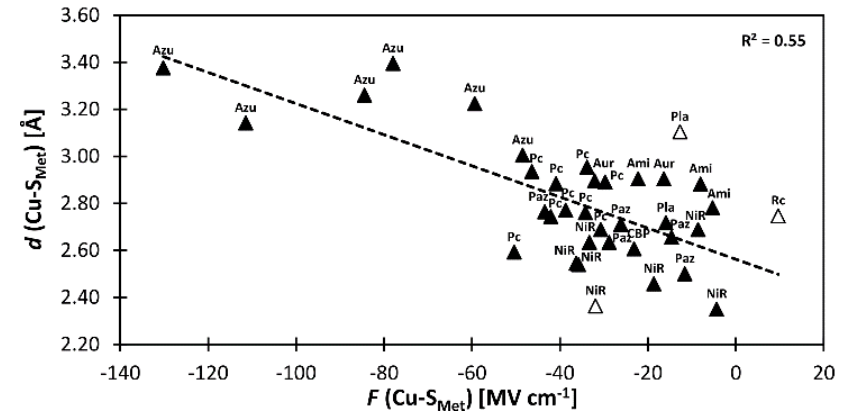

Figure 1. A correlation between $\mathrm{Cu}$-SMet bond dinstances (d(CuSMet)) and projections of the LEF vector in the ("Cu-SMet" ) $\overrightarrow{ }$ orientation ( $\mathrm{F}(\mathrm{Cu}-\mathrm{SMet}))$ for the $\mathrm{BC}$ proteins from Table S1. The empty triangles represent proteins that were crystallized in the reduced form and are excluded from the fit. Ami = amicyanin, Aur $=$ auracyanin, $\mathrm{Azu}=$ azurin, $\mathrm{CBP}=$ cucumber basic protein, $\mathrm{NiR}=$ nitrite reductase, $\mathrm{Pla}=$ plantacyanin, $\mathrm{Pc}=$ plastocyanin, $\mathrm{Paz}=$ pseudoazurin, $\mathrm{Rc}=$ rusticyanin .

C3A/C26A azurin mutant). However, the LEFs are not randomly oriented (Figure 1). Instead, the LEFs projected in the $\overrightarrow{\mathrm{Cu}-\mathrm{S}_{\mathrm{Met}}}$ and $\overrightarrow{\mathrm{Cu}-\mathrm{S}_{\mathrm{Cys}}}$ directions are preferentially negative (cf. average $\boldsymbol{F}\left(\mathrm{Cu}-\mathrm{S}_{\mathrm{Met}}\right)=-35.5 \mathrm{MV} \mathrm{cm}^{-1}$ and $\left.\boldsymbol{F}\left(\mathrm{Cu}-\mathrm{S}_{\mathrm{Cys}}\right)=-47.4 \mathrm{MV} \mathrm{cm}^{-1}\right)$, and the average LEFs projected in the $\overrightarrow{\mathrm{Cu}-\mathrm{N}_{\text {His }}}$ directions are preferentially positive (average $\boldsymbol{F}\left(\mathrm{Cu}-\mathrm{N}_{\mathrm{His}}\right)=+36.4 \mathrm{MV} \mathrm{cm}^{-1}$ ).

We indeed found a passable correlation between the computed $\boldsymbol{F}\left(\mathrm{Cu}-\mathrm{S}_{\mathrm{Met}}\right)$ projection on this bond and the $\mathrm{Cu}-\mathrm{S}_{\text {Met }}$ distance $\left(d\left(\mathrm{Cu}-\mathrm{S}_{\mathrm{Met}}\right)\right.$ ) (Figure 2). This is consistent with a facile electrostatic regulation of the $\mathrm{Cu}-\mathrm{S}_{\mathrm{Met}}$ bond due to a very flat potential energy surface along this coordinate. However, since a significantly worse correlations were found between LEF (or its projections) and other $\mathrm{BC}$ geometric features - such as $d(\mathrm{Cu}-$ $\left.\mathrm{S}_{\mathrm{Cys}}\right)$ or $d\left(\mathrm{Cu}-\mathrm{S}_{\mathrm{Cys}}\right) / d\left(\mathrm{Cu}-\mathrm{S}_{\mathrm{Met}}\right)$ ratio, or the $\tau$ angle ${ }^{\ddagger}$ (Figures S1-S4) - it appears that translation to BC site geometry or their spectral properties might be more intricate. As an example, Szuster et al. demonstrated that other factors, e.g., $\mathrm{Cu}$ ligand-loop hydrophobicity or water accessibility of the $\mathrm{Cu}$ site, also influence the active site geometry, and the $\mathrm{Cu}(\mathrm{II} / \mathrm{I})$ reduction potentials and electronic absorption intensities in the $\mathrm{Cu}_{\mathrm{A}}$-based copper sites. ${ }^{46}$

\section{Coupled nature of the $\mathrm{Cu}-\mathrm{S}_{\mathrm{Met}}$ and $\mathrm{Cu}-\mathrm{S}_{\mathrm{Cys}}$ bonds.}

To evaluate how the change of $d\left(\mathrm{Cu}-\mathrm{S}_{\mathrm{Met}}\right)$ in the $\mathrm{BC}$ site influences $d\left(\mathrm{Cu}-\mathrm{S}_{\mathrm{Cys}}\right)$, we have performed a constrained twodimensional potential energy surface scan in the cluster model of the oxidized poplar plastocyanin (PDB code: 4dp9)

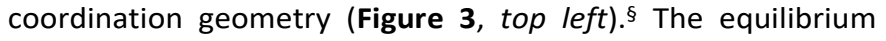
structure is found at the $d\left(\mathrm{Cu}-\mathrm{S}_{\mathrm{Met}}\right)=2.50 \AA$ and $d\left(\mathrm{Cu}-\mathrm{S}_{\mathrm{Cys}}\right)=2.20$ $\AA$. This is slightly distorted from the oxidized plastocyanin crystal-structure geometry $\left(d\left(\mathrm{Cu}-\mathrm{S}_{\mathrm{Met}}\right)=2.78 \AA\right.$ and $d\left(\mathrm{Cu}-\mathrm{S}_{\mathrm{Cys}}\right)=$ $2.16 \AA$ ) $;{ }^{47}$ however, the energy difference is only $\sim 1.8 \mathrm{kcal} \mathrm{mol}^{-1}$. Consistent with Ryde's results (based on the cluster-model approach without protein electrostatics), ${ }^{27}$ we show that $\mathrm{Cu}-$ $\mathrm{S}_{\text {Met }}$ bond is considerably more flexible, with an enthalpic 

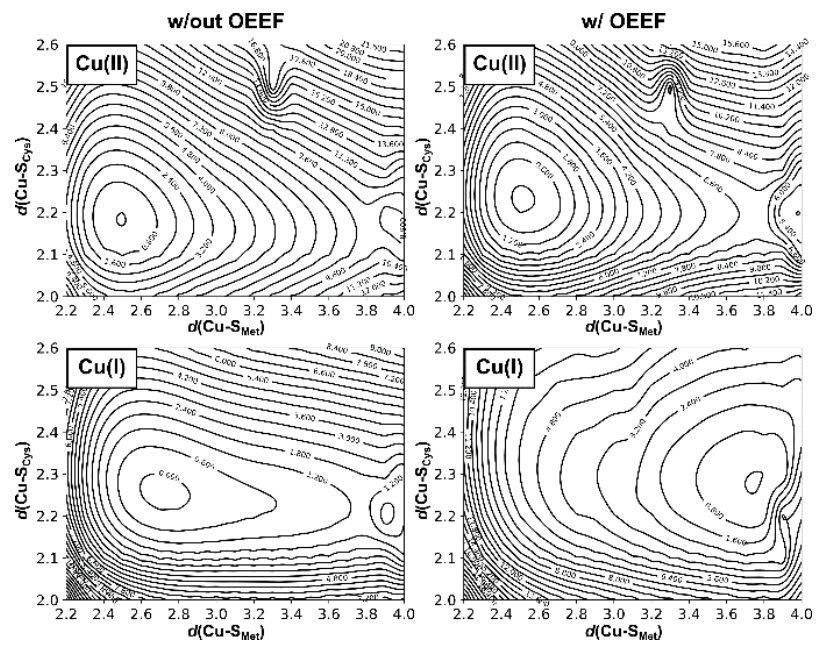

Figure 3. The effect of the protein LEF on the two-dimensional potential energy surfaces correlating the $d\left(\mathrm{Cu}-\mathrm{S}_{\mathrm{cys}}\right)$ and $d\left(\mathrm{Cu}-\mathrm{S}_{\mathrm{Met}}\right)$ bond distances. Graphs for $\mathrm{Cu}(\mathrm{II})$ and $\mathrm{Cu}(\mathrm{I})$ (top and bottom) oxidation states are shown; without the applied external electric field (left) and with applied external electric field (corresponding to the average LEF found in the series of BC proteins; right). The potential energies are plotted in $\mathrm{kcal} \mathrm{mol}^{-1}$ as iso-contour lines and are referenced to the lowest-energy point in each graph.

penalty of only ca. $0.3 \mathrm{kcal} \mathrm{mol}^{-1}$, associated with displacement of $\sim 0.1 \AA$ from the equilibrium geometry. On the other hand, the same displacement of the $\mathrm{Cu}-\mathrm{S}_{\mathrm{Cys}}$ bond costs ca. $1.0 \mathrm{kcal} \mathrm{mol}^{-1}$ in enthalpy. In the $\mathrm{Cu}(\mathrm{I})$ oxidation state, the lowest-energy structure has the $\mathrm{Cu}-\mathrm{S}_{\text {Met }}$ bond stretched to $2.70 \AA$ and is ca. 0.5 $\mathrm{kcal} \mathrm{mol}{ }^{-1}$ below the geometry with $d\left(\mathrm{Cu}-\mathrm{S}_{\mathrm{Met}}\right)=2.50 \AA$ preferred in $\mathrm{Cu}$ (II) (Figure 3, bottom left). However, the potential energy surface is yet shallower in the direction toward $\mathrm{Cu}-\mathrm{S}_{\mathrm{Met}}$ dissociation, with a barrier of only $\sim 2 \mathrm{kcal} \mathrm{mol}^{-1}$ between the two minima with the associated and dissociated Met ligand.

Application of oriented external electric field (OEEF) in the average $\mathrm{BC}$ site orientation and magnitude ( $c f$. Figure 1 ) leads to almost no change in the preferred $\mathrm{Cu}(\mathrm{II})$ geometry or potential energy surface (Figure 3, top right). However, despite small geometric differences, we note that OEEF remarkably reduces the HOMO/LUMO gap between the frontier molecular orbitals (Cu(II) $\alpha$ HOMO and Cu(II) 8 LUMO) by $28 \mathrm{kcal} \mathrm{mol}^{-1}$ and $\mathrm{Cu}(\mathrm{II})-$ $\mathrm{S}_{\text {Cys }}$ bond covalency by $\sim 24 \%$ - as indicated by the change in $\mathrm{Cu}$ and $\mathrm{S}_{\mathrm{Cys}}$ spin densities in the $\mathrm{Cu}(\mathrm{II})$ equilibrium structure (the calculated spin densities are: $\mathrm{Cu}=0.34, \mathrm{~S}_{\mathrm{cys}}=0.51$ at $F=0$ and $\mathrm{Cu}=0.49, \mathrm{~S}_{\mathrm{cys}}=0.27$ at average $F$ experienced by any $\mathrm{BC}$ site) (cf. Table 1). In contrast, there is no stable structure with bonded Met when the OEEF is applied to the $\mathrm{Cu}(\mathrm{I})$ site. Instead, the Met ligand dissociates to $d\left(\mathrm{Cu}-\mathrm{S}_{\mathrm{Met}}\right)=3.90 \AA$. This suggests that, although the enzyme geometry would be enthalpically favored in $\mathrm{Cu}(\mathrm{I})$ oxidation state without LEF, in the average BC site (with the LEF opposing $\overrightarrow{\mathrm{Cu}-\mathrm{S}_{\mathrm{Met}}}$ ) the $\mathrm{Cu}-\mathrm{S}_{\text {Met }}$ bond must be covalently constrained by the protein, in order to compensate both the enthalpic and the entropic penalties. Herein, the average LEF was found to introduce an enthalpic strain of $\sim 4$ $\mathrm{kcal} \mathrm{mol}^{-1}$ compared to an unconstrained geometry. We suggest
Table 1. Calculated $\mathrm{Cu}(\mathrm{II}) \alpha \mathrm{HOMO}$ and $\mathrm{Cu}(\mathrm{II}) \beta \mathrm{LUMO}$ energies and the Mulliken spin densities of the selected atoms (at the B3LYP/def2TZVP level) for the equilibrium structure from Figure 3.

\begin{tabular}{ccc}
\hline Orbital energy [eV] & w/out OEEF & w/ OEEF \\
\hline $\mathrm{Cu}(\mathrm{II}) \alpha$ HOMO & -7.21 & -6.50 \\
$\mathrm{Cu}(\mathrm{II})$ B LUMO & -4.75 & -5.25 \\
\hline Mulliken spin density $[e]$ & w/out OEEF & w/ OEEF \\
\hline $\mathrm{Cu}$ & 0.34 & 0.49 \\
$\mathrm{SCys}$ & 0.51 & 0.27 \\
$\mathrm{~S}_{\mathrm{Met}}$ & 0.08 & 0.05 \\
$\mathrm{~N}_{\text {His }}{ }^{\text {al }}$ & 0.06 & 0.17 \\
\hline
\end{tabular}

[a] Combined spin density on both coordinating $\mathrm{N}_{\text {His }}$ atoms.

the enthalpic penalty should be added to an entropic penalty of $\sim 4.5 \mathrm{kcal} \mathrm{mol}^{-1}$ proposed by Solomon, ${ }^{35}$ leading to the total strain energy of $\sim 8.5 \mathrm{kcal} \mathrm{mol}^{-1}$ that is associated with constraining the Met ligand in an average $\mathrm{Cu}(\mathrm{I}) \mathrm{BC}$ site.

\section{Effect of the local electric field on the blue copper properties.}

Although there is no significant geometrical change in the $\mathrm{Cu}$ (II) $\mathrm{BC}$ site under OEEF, the quantum chemical calculations revealed that frontier molecular orbitals are substantially altered in energy, along with a decrease of the $\mathrm{Cu}(\mathrm{II})-\mathrm{S}_{\mathrm{Cys}}$ bond covalency by $\sim 24 \%$. A lower covalency is quantified by the lower Mulliken spin density at the $\mathrm{S}_{\mathrm{Cys}}$ atom, indicating smaller $\mathrm{S}_{\mathrm{Cys}} 3 \mathrm{p}$ and $\mathrm{Cu}$ $3 d_{x 2-y 2}$ orbitals overlap and hence bonding (Table 1). ${ }^{35}$ Similarly, smaller bonding in $\mathrm{Cu}(\mathrm{II}) \alpha \mathrm{HOMO}$ can be translated into lower antibonding character in $\mathrm{CU}$ (II) $B$ LUMO, which is exhibited by a significantly decreased Cu(II) $B$ LUMO energy under OEEF, by $\sim 11.5 \mathrm{kcal} \mathrm{mol}^{-1}$. By evaluating the individual contributions from $F\left(C u-S_{\text {Cys }}\right)$ and $F\left(C u-S_{\text {Met }}\right)$ projections of the LEF ( $c f$. Table S2, where we applied OEEF only in the $\overrightarrow{\mathrm{Cu}-\mathrm{S}_{\mathrm{Cys}}}$ or $\overrightarrow{\mathrm{Cu}-\mathrm{S}_{\mathrm{Met}}}$ direction), we can conclude that the decreased $\mathrm{Cu}(\mathrm{II})-\mathrm{S}_{\mathrm{Cys}}$ bond covalency and $\mathrm{Cu}(\mathrm{II}) \mathrm{B}$ LUMO energy are caused by $\mathrm{F}\left(\mathrm{Cu}-\mathrm{S}_{\mathrm{Cys}}\right)$ projection of the LEF, which exhibits decreased $\mathrm{S}_{\mathrm{Cys}}$ spin density by $0.21 e$ and $\mathrm{Cu}(\mathrm{II}) \mathrm{B}$ LUMO energy by $7.7 \mathrm{kcal} \mathrm{mol}^{-1}$. On the other hand, the average OEEF in $\overrightarrow{\mathrm{Cu}-\mathrm{S}_{\mathrm{Met}}}$ projection increases the $\mathrm{Cu}(\mathrm{II})-\mathrm{S}_{\mathrm{Cys}}$ bond covalency by $\sim 6 \%$ with $\mathrm{Cu}$ (II) 6 LUMO decrease by only $0.7 \mathrm{kcal}$ $\mathrm{mol}^{-1}$. Note that the projections are not orthogonal and their effects thus cannot be fully decoupled.

Many BC features were previously correlated with the $\mathrm{Cu}(\mathrm{II})$ $S_{C y s}$ bond covalency, and our results therefore suggest that LEF may play a critical role in tuning the $\mathrm{BC}$ properties. For instance, the $\mathrm{BC}$ proteins' electronic absorption spectra are characterized by the distinctive absorption bands at $\sim 600 \mathrm{~nm}$ and $\sim 450 \mathrm{~nm}$. The $\mathrm{BC}$ proteins have stronger absorption intensity at the lowerenergy thiolate $\pi$-to-Cu charge-transfer transition and weaker absorption intensity at the higher-energy $\sigma$-to- $\mathrm{Cu}$ chargetransfer transition (Figure 4). Inversely, the $\varepsilon_{600}$ and $\varepsilon_{450}$ 


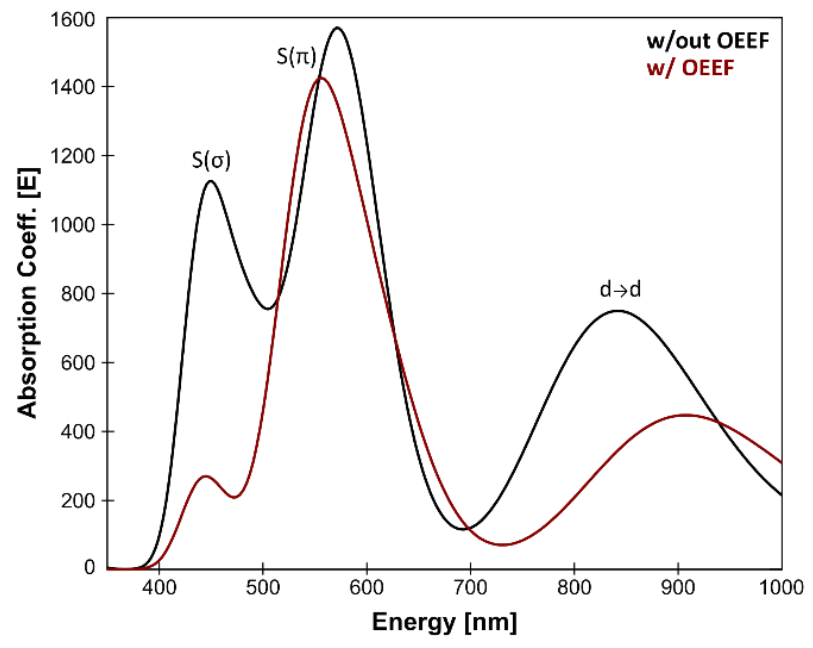

Figure 4. Calculated TD-DFT spectra for the equilibrium structure from Figure 3; without the applied external electric field (black) and with applied external electric field (corresponding to the average LEF found in the series of BC proteins; red). A lower $\mathrm{Cu}\left(\mathrm{III}-\mathrm{S}_{\mathrm{cys}}\right.$ bond covalency under applied OEEF is translated into a considerably smaller $\sigma$-to-Cu charge-transfer transition at $\sim 450 \mathrm{~nm}$.

intensities are reversed for the normal tetragonal cupric complexes and green copper proteins. A lower $\mathrm{Cu}(\mathrm{II})-\mathrm{S}_{\mathrm{cys}}$ bond covalency in our computational model due to lower $F\left(\mathrm{Cu}_{\mathrm{C}} \mathrm{S}_{\mathrm{cys}}\right)$ is thus consistent with a shift toward a more pronounced blue copper absorption features (cf. Figure 4). Hence, the $\varepsilon_{450} / \varepsilon_{600}$ ratio is $\sim 0.7$ for the equilibrium $\mathrm{Cu}(\mathrm{II})$ geometry from Figure 3 without the applied field, while the $\sigma$-to-Cu charge-transfer intensity is significantly diminished by the OEEF, leading to an $\varepsilon_{450} / \varepsilon_{600}$ ratio of $\sim 0.2$. Significantly, the $\varepsilon_{450} / \varepsilon_{600}$ ratio is regularly utilized as a measure of the cupric coordination geometry. ${ }^{2}$ Its sensitivity to the local intramolecular electric field exerted on the $\mathrm{Cu}$ site is striking.

The effect of $F\left(\mathrm{Cu}-\mathrm{S}_{\mathrm{Cys}}\right)$ on the electronic absorption spectra is further reflected for blue copper and green copper proteins in Table S1. While the average $F\left(\mathrm{Cu}-\mathrm{S}_{\mathrm{Cys}}\right)$ is $-26.7 \mathrm{MV} \mathrm{cm}^{-1}$ for nitrite reductases (green copper proteins), the remaining proteins exhibit $F\left(\mathrm{Cu}-\mathrm{S}_{\mathrm{Cys}}\right)$ of $-52.3 \mathrm{MV} \mathrm{cm}^{-1}$ (i.e., $\sim 25 \mathrm{MV} \mathrm{cm}^{-1}$ lower). We also note that $F\left(\mathrm{Cu}-\mathrm{S}_{\mathrm{Met}}\right)$ projection of the LEF is as well higher for nitrite reductases by $\sim 15 \mathrm{MV} \mathrm{cm}^{-1}$, which is consistent with a shorter $d\left(\mathrm{Cu}-\mathrm{S}_{\mathrm{Met}}\right)$ witnessed in green copper proteins ( $c f$. correlation of $d\left(\mathrm{Cu}-\mathrm{S}_{\mathrm{Met}}\right)$ vs. $F\left(\mathrm{Cu}-\mathrm{S}_{\mathrm{Met}}\right)$ for nitrite reductases in Figure 2).

As for the effect of LEF on the $\mathrm{Cu}(\mathrm{II} / \mathrm{I})$ reduction potential, a lower $\mathrm{Cu}(\mathrm{II})-\mathrm{S}_{\mathrm{cys}}$ covalency indicates a weaker $\mathrm{Cu}-\mathrm{S}_{\mathrm{cys}}$ bond, which agrees with a destabilization of the oxidized $\mathrm{Cu}$ (II) state and thus higher $\mathrm{Cu}(\mathrm{II} / \mathrm{I})$ reduction potential. According to Hadt et al., the $\mathrm{Cu}(\mathrm{I})$ adiabatic ionization energy (i.e., the inverse of the $\mathrm{Cu}(\mathrm{II})$ adiabatic electron affinity) is decreased due to lowered $\mathrm{Cu}(\mathrm{II})-\mathrm{S}_{\mathrm{Cys}}$ covalency by $\sim 10 \mathrm{mV}$ per $1 \%$ decrease of the spin density on $\mathrm{S}_{\mathrm{Cys} .}{ }^{48}$ Therefore, on average, we might assign the effect of $\sim 240 \mathrm{mV}$ increase in the $\mathrm{Cu}$ (II) electron affinity due to lowered $\mathrm{Cu}(\mathrm{II})-\mathrm{S}_{\mathrm{Cys}}$ covalency in an average BC. Similarly, when the average OEEF is applied, the redox-active molecular orbital (i.e., $\mathrm{Cu}$ (II) 8 LUMO) is decreased in energy by ca. 11.5 $\mathrm{kcal} \mathrm{mol}^{-1}$ (cf. Table 1), consistent with an increase in the $\mathrm{Cu}(\mathrm{II})$ electron affinity by ca. $500 \mathrm{mV}$ (i.e., the effect that is twice as high as for the $\mathrm{Cu}(\mathrm{II})$ electron affinity predicted from a decreased covalency). With simplification, we can thus attribute the increase in the $\mathrm{Cu}$ (II) electron affinity to a comparable covalent and non-local electrostatic contributions to the $\mathrm{Cu}(\mathrm{II}) \mathrm{B}$ LUMO energy.

Finally, note that $F\left(\mathrm{Cu}-\mathrm{S}_{\mathrm{Cys}}\right)$ and $F\left(\mathrm{Cu}-\mathrm{S}_{\mathrm{Met}}\right)$ contribute to the overall $\mathrm{Cu}(\mathrm{II} / \mathrm{I})$ reduction potential in the same direction. Although a negative $\mathrm{F}\left(\mathrm{Cu}-\mathrm{S}_{\text {Met }}\right)$ leads to a higher $\mathrm{Cu}(\mathrm{II})-\mathrm{S}_{\text {Cys }}$ covalency by $\sim 6 \%$ (decreasing the $\mathrm{Cu}(\mathrm{II})$ electron affinity by $\sim 60$ $\mathrm{mV})$, there is a significant antagonistic contribution of $F\left(\mathrm{Cu}-\mathrm{S}_{\mathrm{Met}}\right)$ to the $\mathrm{Cu}(\mathrm{I})$ strain energy, increasing the $\mathrm{Cu}(\mathrm{II} / \mathrm{I})$ reduction potential by $170 \mathrm{mV}$ (vide supra). All in all, the average LEF in $\mathrm{BC}$ proteins appears to increase the $\mathrm{Cu}(\mathrm{II} / \mathrm{I})$ reduction potential on aggregate by ca. $670 \mathrm{mV}$, coming from the increased $\mathrm{Cu}(\mathrm{II})$ $\mathrm{S}_{\mathrm{cys}}$ covalency $(240 \mathrm{mV}$ ), non-local electrostatic contributions to the $\mathrm{Cu}(\mathrm{II}) \mathrm{B}$ LUMO energy $(260 \mathrm{mV})$, and increased $\mathrm{Cu}(\mathrm{I})$ strain energy $(170 \mathrm{mV})$.

\section{Electrostatic contribution to the azurin $\mathrm{Cu}(\mathrm{II} / \mathrm{I})$ reduction potentials.}

To further support the idea of LEF regulating the BC sites' electronic structure, including $\mathrm{Cu}(\mathrm{II} / \mathrm{I})$ reduction potentials, we have calculated the LEFs in a series of azurin variants from ref. 49. Specifically, we have analyzed all of the variants not containing mutations in the $\mathrm{Cu}$ first shell\$§ (i.e., N47S, F114N, $\mathrm{F} 114 \mathrm{P}$, and N47S/F114N), which were generated from the available PDB structures of the wild-type azurin (4azu), and N47S/F114N (3jtb) and F114P/M121Q (3in0) azurin variants.

As compared to wild-type azurin, the N47S, F114N, and $\mathrm{N} 47 \mathrm{~S} / \mathrm{F} 114 \mathrm{~N}$ have higher $\mathrm{Cu}(\mathrm{II} / \mathrm{I})$ reduction potentials, which are consistent with their lower (more negative) $F\left(\mathrm{Cu}_{\mathrm{C}} \mathrm{S}_{\mathrm{cys}}\right)$ projections of the LEF (Figure 5A). Oppositely, a higher F(Cu-S $\left.\mathrm{S}_{\text {cys }}\right)$ of the F114P variant agrees remarkably well with lower $\mathrm{Cu}(\mathrm{II} / \mathrm{I})$ reduction potential. Since the regression coefficient $\left(R^{2}\right)$ in Figure $\mathbf{5 A}$ is close to unity, we can estimate an increase in reduction potential due to $F\left(\mathrm{Cu}-\mathrm{S}_{\mathrm{Cys}}\right)$ as $-12.5 \mathrm{mV} / 1 \mathrm{MV} \mathrm{cm}^{-1}$. This also agrees well with the computational model presented above correlating the OEEF with the $\mathrm{CU}$ (II) 8 LUMO energy and $\mathrm{Cu}(\mathrm{I})$ strain energy contributions to the $\mathrm{Cu}(\mathrm{II} / \mathrm{I})$ reduction potentials (i.e., $-670 \mathrm{mV} / 47.4 \mathrm{MV} \mathrm{cm}^{-1}=-14.1 \mathrm{mV} / 1 \mathrm{MV} \mathrm{cm}^{-}$ $\left.{ }^{1}\right)$. We note in passing that $F\left(\mathrm{Cu}-\mathrm{S}_{\mathrm{Cys}}\right)$ projection of the LEF in the azurin variants also weakly correlates with the experimentally determined $\mathrm{Cu}(\mathrm{II})-\mathrm{S}_{\mathrm{Cys}}$ bond covalencies: $54 \%$ for F114P, $45 \%$ for wild-type azurin, $43 \%$ for F114N, and $31 \%$ for N47S. ${ }^{48}$

An excellent correlation in Figure 5A suggests that determinants of the reduction potentials in the azurin variants are purely electrostatic. However, this study benefits from using 

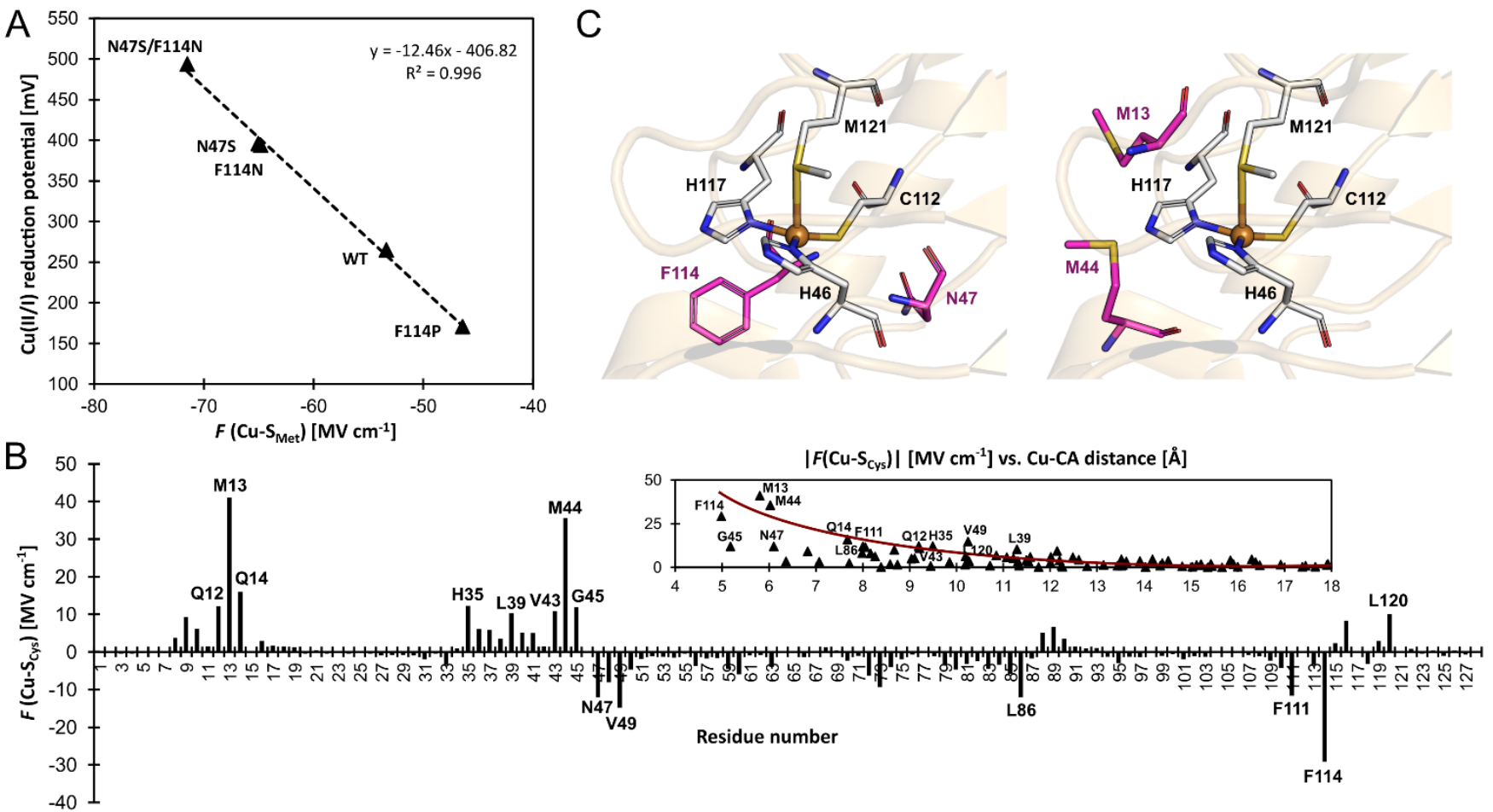

$\left|F\left(\mathrm{Cu}-\mathrm{S}_{\mathrm{Cys}}\right)\right|\left[\mathrm{MV} \mathrm{cm}^{-1}\right]$ vs. Cu-CA distance $[\AA ̊]$

Figure 5. A: Correlation between experimental one-electron $\mathrm{Cu}(\mathrm{II} / \mathrm{I})$ reduction potentials (referenced to normal hydrogen electrode) vs. $\boldsymbol{F}(\mathrm{Cu}-\mathrm{S} \mathrm{Cys})$ projection of the LEF in a series of azurin variants from ref. ${ }^{[49]}$. B: A contribution of each residue's side chain toward $\boldsymbol{F}(\mathrm{Cu}-\mathrm{Scys})$ in the wild-type azurin. Note that side chains of the ligating (first-shell) residues are not included. A more significant contribution to $\boldsymbol{F}\left(\mathrm{Cu}_{\mathrm{C}} \mathrm{S} \mathrm{cys}\right)$ is from the residues closer to the Cu site; the contribution becomes negligible when $\mathrm{Cu}-\mathrm{C}_{\alpha}$ distance exceeds $\sim 15 \AA$. C: The second-coordination shell residues subjected to mutation to alter azurin $\mathrm{Cu}(\mathrm{II} / \mathrm{I})$ reduction potential (in purple) investigated in ref. ${ }^{[49]}$ (left) and suggested in this work (right).

the crystal structures, which already reflect the effect of the field. For example, the crystal structure of the F114P variant is missing an important Cys... HN- $\mathrm{C}_{\alpha}-\mathrm{CO}$ hydrogen bond. However, if the F114P mutant is modeled by a simple amino acid replacement in the wild-type azurin, a non-equilibrated structure with that hydrogen bond is yielded, and a much lower $\mathrm{F}\left(\mathrm{Cu}-\mathrm{S}_{\mathrm{Cys}}\right)$ by $\sim 14 \mathrm{MV} \mathrm{cm}^{-1}$ is predicted, which significantly deviates from the fit. The crystal structure or a structure produced by extensive molecular dynamics equilibration is needed for accurate predictions. Still, the correlation between the change of the reduction potential and the local electric field calculated directly from the crystal structure represents a powerful and economic concept that can be utilized, e.g., for designing $B C$ variants with specific redox properties.

In this regard, we have analyzed the contributions of individual residues in the wild-type azurin (4azu) toward the observed $F\left(\mathrm{Cu}_{\mathrm{S}} \mathrm{S}_{\mathrm{Cys}}\right)$ (see Note $\mathbf{S 2}$ in the SI for details); the effect of the residues' side chains is presented in Figure 5B (the overall effect of each residue and the backbone-only contributions are shown in Figure 56). Not surprisingly, the electric field beyond the first- coordination sphere is mainly dictated by the side chains of the second sphere residues, and the effect on the $\mathrm{F}\left(\mathrm{Cu}-\mathrm{S}_{\mathrm{Cys}}\right)$ drops significantly with the increasing distance of a residue from $\mathrm{Cu}$ ( $c f$. Figure 5B and Figure S7). However, some impactful residues in the second sphere have not been experimentally examined. Especially, we hypothesize that $13 \mathrm{M}$ and $44 \mathrm{M}$ on the opposite side of the first-shell $112 \mathrm{C}$ generate substantial dipole moments that should influence the azurin redox properties considerably (Figure 5B-C). By removing both of the dipoles via mutating the Met residues, we propose that it should be possible to lower $F\left(C u-S_{c y s}\right)$ by as much as $80 \mathrm{MV} \mathrm{cm}^{-}$ 1 , and thus increase the reduction potential roughly by $\sim 1 \mathrm{~V}$ (evaluation of the protein structure upon mutation is required for a more accurate prediction).

\section{Conclusions}

By examining an extensive series of blue copper proteins' crystal structures, we show that the protein scaffolds that host blue copper sites are not mere spectators of their function. Instead, the proteins' local electric fields can regulate multiple geometric and electronic properties typical of blue copper sites in biology. Specifically, we demonstrate that the local electric fields are oriented in a definite way throughout the blue copper protein family to modulate the copper interactions with its ligating residues. By orienting the electric field preferentially in the direction opposite of the $\overrightarrow{\mathrm{Cu}-\mathrm{S}_{\mathrm{Cys}}}$ and $\overrightarrow{\mathrm{Cu}-\mathrm{S}_{\mathrm{Met}}}$ vectors in the copper first shell, the proteins make the $\mathrm{Cu}-\mathrm{S}$ bonds considerably weaker than those in the isolated blue copper sites in a vacuum. 
In the context of entatic/rack-induced concepts, the $F(\mathrm{Cu}$ $\mathrm{S}_{\text {Met }}$ ) projection of the field pushes the axial Met ligand to dissociate from the $\mathrm{Cu}(\mathrm{I})$ center, though the entities are still held together by the protein. Hence, the electric field can be seen as an additional element adding to the $\mathrm{Cu}(\mathrm{I})$ sites' covalent strain. In an average blue copper site, we have estimated an enthalpic destabilization of the constrained $\mathrm{Cu}(\mathrm{I})$ active site by $\sim 4 \mathrm{kcal}$ $\mathrm{mol}^{-1}$ due to local electric field.

Importantly, a weakening of the $\mathrm{Cu}-\mathrm{S}_{\mathrm{Cys}}$ bond appears to considerably influence many blue copper spectroscopic properties. Besides others, a weaker $\mathrm{Cu}_{\mathrm{S}} \mathrm{S}_{\mathrm{Cys}}$ is consistent with decreasing the $\mathrm{Cu}(\mathrm{II})-\mathrm{S}_{\mathrm{Cys}}$ bond covalency, which, in turn, affects the relative absorption intensities of $\mathrm{Cu}(\mathrm{II})$ at $450 \mathrm{~nm}$ and 600 $\mathrm{nm}$. We have demonstrated that, while the $\varepsilon_{450} / \varepsilon_{600}$ ratio is $\sim 0.7$ for the isolated equilibrium $\mathrm{Cu}$ (II) geometry in the plastocyanin active site, the local electric field oriented in the direction opposite of $\overrightarrow{\mathrm{Cu}-\mathrm{S}_{\mathrm{Cys}}}$ (average projection of $F\left(\mathrm{Cu}-\mathrm{S}_{\mathrm{Cys}}\right)$ is $-47.4 \mathrm{MV}$ $\mathrm{cm}^{-1}$ ) is necessary to shift the $\varepsilon_{450} / \varepsilon_{600}$ to $\sim 0.2$, consistent with that of the regular blue copper sites. On the contrary, the green copper proteins exhibit much lower magnitudes of the local electric fields (average $F\left(\mathrm{Cu}-\mathrm{S}_{\mathrm{Cys}}\right)$ is $-26.7 \mathrm{MV} \mathrm{cm}{ }^{-1}$ ), in accordance with their higher $\varepsilon_{450} / \varepsilon_{600}$ ratio.

The electric field also contributes to the high $\mathrm{Cu}(\mathrm{II} / \mathrm{I})$ reduction potentials of the blue copper sites. On average, it was found to be accountable for an increase of the $\mathrm{Cu}(\mathrm{II} / \mathrm{I})$ reduction potentials by ca. $670 \mathrm{mV}$, originating from a lower $\mathrm{Cu}(\mathrm{II})-\mathrm{S}_{\mathrm{Cys}}$ covalency $(240 \mathrm{mV})$, non-local contributions to a lower $\mathrm{Cu}$ (II) $b$ LUMO energy $(260 \mathrm{mV})$, and increased $\mathrm{Cu}(\mathrm{I})$ strain energy (170 $\mathrm{mV})$.

Last but not least, we have observed that local electric field is a critical determinant of the $\mathrm{Cu}(\mathrm{II} / \mathrm{I})$ reduction potentials, when comparing different variants of otherwise identical blue copper sites. In a series of azurin variants that introduced mutations in the second-coordination sphere of the Cu site, we have shown that the change of reduction potential can be accurately described by the change in the local electric field exerted on the $\mathrm{Cu}-\mathrm{S}_{\mathrm{cys}}$ bond in the equilibrium structure. We suggest that this concept could be utilized for designing protein variants with desired redox properties. Following our analysis, we propose new targets for mutagenetic studies, which have not been questioned thus far, and which contribute significantly to $F\left(\mathrm{Cu}-\mathrm{S}_{\mathrm{Cys}}\right)$ and should alter the reduction potential.

\section{Acknowledgements}

Financial support comes from the NIH 1R01GM134047 grant to A.N.A.. We also acknowledge the UCLA-IDRE cluster Hoffman2 and XSEDE for computational resources.

\section{Notes and references}

$\ddagger \quad \tau=\left(360^{\circ}-(\alpha+\beta)\right) /\left(141^{\circ}\right)$, where $\alpha$ and $\beta$ are the two largest angles between the $\mathrm{Cu}$ ligating atoms. The parameter $\tau$ was introduced by Yang et al. ${ }^{50}$ as a four-coordinate geometry index ranging from perfect tetrahedral $(\tau=1)$ to perfect square planar $(\tau=0)$.

$\S$ In the two-dimensional scan, we incrementally altered the $\mathrm{Cu}-\mathrm{S}_{\text {cys }}$ and $\mathrm{Cu}-\mathrm{S}_{\mathrm{Met}}$ distances by $0.1 \AA$, while keeping the rest of the coordination geometry (i.e., angles between $\mathrm{Cu}$ ligating atoms $(\tau)$, and $\mathrm{Cu}-\mathrm{N}_{\text {His }}$ distances) at the crystal positions. See Computational Details section in the SI.

$\S \S$ In our approach, the LEF is analyzed outside the first-shell sphere of ligands (i.e., charges of the side-chains of ligating residues are zeroed). Therefore, any mutations in the $\mathrm{Cu}$ first shell would not result in different LEFs.

1 J. Liu, S. Chakraborty, P. Hosseinzadeh, Y. Yu, S. Tian, I. Petrik, A. Bhagi and Y. Lu, Chem. Rev., 2014, 114, 4366-4469.

2 E. I. Solomon and R. G. Hadt, Coord. Chem. Rev., 2011, 255, 774789.

3 E. I. Solomon, R. K. Szilagyi, S. DeBeer George and L. Basumallick, Chem. Rev., 2004, 104, 419-458.

4 H. B. Gray, B. G. Malmström and R. J. P. Williams, JBIC J. Biol. Inorg. Chem., 2000, 5, 551-559.

5 E. I. Solomon, J. W. Hare and H. B. Gray, Proc. Natl. Acad. Sci., 1976, 73, 1389-1393.

6 J. M. Guss and H. C. Freeman, J. Mol. Biol., 1983, 169, 521-563.

7 L. Broman, B. G. Malmström, R. Aasa and T. Vänngård, Biochim. Biophys. Acta, 1963, 75, 365-376.

8 E. I. Solomon, M. J. Baldwin and M. D. Lowery, Chem. Rev., 1992, 92, 521-542.

9 E. I. Solomon and M. D. Lowery, Science (80-. )., 1993, 259, 15751581.

10 E. I. Solomon, K. W. Penfield and D. E. Wilcox, in Copper, Molybdenum, and Vanadium in Biological Systems, eds. B. A. Averill, L. R. Briggs, N. D. Chasteen, T. R. Gilbert, K. Kustin, G. C. McLeod, K. W. Penfield, E. I. Solomon and D. E. Wilcox, Springer Berlin Heidelberg, Berlin, Heidelberg, 1983, pp. 1-57.

11 D. W. Randall, S. D. George, B. Hedman, K. O. Hodgson, K. Fujisawa and E. I. Solomon, J. Am. Chem. Soc., 2000, 122, 11620-11631.

12 L. B. LaCroix, S. E. Shadle, Y. Wang, B. A. Averill, B. Hedman, K. O. Hodgson and E. I. Solomon, J. Am. Chem. Soc., 1996, 118, 77557768.

13 R. J. P. Williams, Inorganica Chim. Acta Rev., 1971, 5, 137-155.

14 R. Malkin and B. G. Malmström, Adv. Enzymol. Relat. Areas Mol. Biol., 1970, 177-244.

15 B. G. Malmström, B. Reinhammar and T. Vänngård, Biochim. Biophys. Acta - Bioenerg., 1970, 205, 48-57.

16 A. L. Le Sueur, R. N. Schaugaard, M.-H. Baik and M. C. Thielges, J. Am. Chem. Soc., 2016, 138, 7187-7193.

17 J. M. Guss, H. D. Bartunik and H. C. Freeman, Acta Crystallogr. Sect. $B, 1992,48,790-811$. 
18 J. M. Guss, P. R. Harrowell, M. Murata, V. A. Norris and H. C. Freeman, J. Mol. Biol., 1986, 192, 361-387.

19 J. A. Guckert, M. D. Lowery and E. I. Solomon, J. Am. Chem. Soc., 1995, 117, 2817-2844.

20 W. E. B. Shepard, B. F. Anderson, D. A. Lewandoski, G. E. Norris and E. N. Baker, J. Am. Chem. Soc., 1990, 112, 7817-7819.

21 A. Romero, C. W. G. Hoitink, H. Nar, R. Huber, A. Messerschmidt and G. W. Canters, J. Mol. Biol., 1993, 229, 1007-1021.

22 B. G. Karlsson, R. Aasa, B. G. Malmström and L. G. Lundberg, FEBS Lett., 1989, 253, 99-102.

23 B. L. Vallee and R. J. Williams, Proc. Natl. Acad. Sci., 1968, 59, 498505.

24 B. G. Malmström, Eur. J. Biochem., 1994, 223, 711-718.

25 J. R. Winkler, P. Wittung-Stafshede, J. Leckner, B. G. Malmström and H. B. Gray, Proc. Natl. Acad. Sci., 1997, 94, 4246 LP - 4249.

26 R. A. Marcus and N. Sutin, Biochim. Biophys. Acta-Rev. Bioenerg., 1985, 811, 265-322.

27 U. Ryde, M. H. M. Olsson, B. O. Roos, J. O. A. De Kerpel and K. Pierloot, JBIC J. Biol. Inorg. Chem., 2000, 5, 565-574.

28 H. A. Jahn, E. Teller and F. G. Donnan, Proc. R. Soc. London. Ser. A Math. Phys. Sci., 1937, 161, 220-235.

29 D. W. Randall, D. R. Gamelin, L. B. LaCroix and E. I. Solomon, JBIC J. Biol. Inorg. Chem., 2000, 5, 16-29.

30 R. H. Holm, P. Kennepohl and E. I. Solomon, Chem. Rev., 1996, 96, 2239-2314.

31 E. I. Solomon, K. W. Penfield, A. A. Gewirth, M. D. Lowery, S. E. Shadle, J. A. Guckert and L. B. LaCroix, Inorganica Chim. Acta, 1996, 243, 67-78.

32 L. B. LaCroix, D. W. Randall, A. M. Nersissian, C. W. G. Hoitink, G. W. Canters, J. S. Valentine and E. I. Solomon, J. Am. Chem. Soc., 1998, 120, 9621-9631.

33 S. E. Shadle, J. E. Penner-Hahn, H. J. Schugar, B. Hedman, K. O. Hodgson and E. I. Solomon, J. Am. Chem. Soc., 1993, 115, 767-776.

34 A. A. Gewirth and E. I. Solomon, J. Am. Chem. Soc., 1988, 110, 38113819.

35 K. W. Penfield, A. A. Gewirth and E. I. Solomon, J. Am. Chem. Soc., 1985, 107, 4519-4529.

36 S. Larsson, A. Broo and L. Sjoelin, J. Phys. Chem., 1995, 99, 48604865.

37 P. Wittung-Stafshede, M. G. Hill, E. Gomez, A. J. Di Bilio, B. G. Karlsson, J. Leckner, J. R. Winkler, H. B. Gray and B. G. Malmström, JBIC J. Biol. Inorg. Chem., 1998, 3, 367-370.

38 A. S. Brill, Biophys. Chem., 1999, 80, 129-138.

39 S. Ghosh, X. Xie, A. Dey, Y. Sun, C. P. Scholes and E. I. Solomon, Proc. Natl. Acad. Sci., 2009, 106, 4969-4974.

40 W. R. Hagen, Metallomics, 2019, 11, 1768-1778.

41 J. Stanek, A. Hoffmann and S. Herres-Pawlis, Coord. Chem. Rev., 2018, 365, 103-121.

42 C. A. Hurd, N. A. Besley and D. Robinson, J. Comput. Chem., 2017, 38, 1431-1437.
43 N. J. Fowler, C. F. Blanford, J. Warwicker and S. P. de Visser, Chem. A Eur. J., 2017, 23, 15436-15445.

44 D. Bím and A. N. Alexandrova, 10.26434/chemrxiv.13615853.v1, , DOI:10.26434/chemrxiv.13615853.v1.

45 D. Shirvanyants, A. N. Alexandrova and N. V Dokholyan, Bioinformatics, 2011, 27, 1327-1329.

46 J. Szuster, U. A. Zitare, M. A. Castro, A. J. Leguto, M. N. Morgada, A. J. Vila and D. H. Murgida, Chem. Sci., 2020, 11, 6193-6201.

47 G. S. Kachalova, A. C. Shosheva, G. P. Bourenkov, A. A. Donchev, M. I. Dimitrov and H. D. Bartunik, J. Inorg. Biochem., 2012, 115, 174181.

48 R. G. Hadt, N. Sun, N. M. Marshall, K. O. Hodgson, B. Hedman, Y. Lu and E. I. Solomon, J. Am. Chem. Soc., 2012, 134, 16701-16716.

49 N. M. Marshall, D. K. Garner, T. D. Wilson, Y. G. Gao, H. Robinson, M. J. Nilges and Y. Lu, Nature, 2009, 462, 113-116.

50 L. Yang, D. R. Powell and R. P. Houser, Dalt. Trans., 2007, 955-964. 